\title{
Hydraulic properties and embolism in small-diameter roots of five temperate broad-leaved tree species with contrasting drought tolerance
}

\author{
Paul Köcher • Viviana Horna • Ingo Beckmeyer • \\ Christoph Leuschner
}

Received: 11 November 2011 / Accepted: 26 January 2012 / Published online: 22 February 2012

(C) The Author(s) 2012. This article is published with open access at Springerlink.com

\begin{abstract}
- Context It has been estimated that about half of a plant's total hydraulic resistance is located belowground, but it is not well known how temperate tree species differ in root hydraulic properties and how these traits vary with the species' drought tolerance.

- Aims We examined root anatomical and hydraulic traits in five broad-leaved tree species with different drought tolerance, analyzed the relation between root anatomy and hydraulic conductivity and root embolism, and investigated the relation of these traits to the species' drought tolerance.

- Methods In small-diameter roots $(2-6 \mathrm{~mm})$, we measured vessel diameters and vessel density, specific hydraulic conductivity, and the percental loss of conductivity ("native" embolism) during summer in a mixed forest.

- Results Specific conductivity was positively related to vessel diameter but not to vessel density. Drought-tolerant Fraxinus showed the smallest mean vessel diameters and drought-sensitive Fagus the largest. Specific conductivity was highly variable among different similar-sized roots of the same species with a few roots apparently functioning as "high-conductivity roots".

- Conclusion The results show that coexisting tree species can differ largely in root hydraulic traits with more drought-
\end{abstract}

Handling Editor: Erwin Dreyer

Contribution of co-authors Ingo Beckmeyer contributed to data collection and analysis. Viviana Horna and Christoph Leuschner supervised the work and revised the paper.

P. Köcher $(\bowtie) \cdot$ V. Horna $\cdot$ I. Beckmeyer $\cdot$ C. Leuschner

Plant Ecology, Albrecht-von-Haller Institute for Plant Sciences,

University of Göttingen,

Untere Karspüle 2,

37073 Göttingen, Germany

e-mail: pkoeche@gwdg.de sensitive trees apparently having larger mean vessel diameters in their roots than tolerant species. However, this difference was not related to the observed root conductivity losses due to embolism.

Keywords Acer pseudoplatanus · Carpinus betulus · Coarse roots $\cdot$ Drought tolerance $\cdot$ Fagus sylvatica $\cdot$ Fraxinus excelsior $\cdot$ Root hydraulic conductivity $\cdot$ Root embolism . Tilia cordata . Vessel diameter

\section{Introduction}

A key direction of plant adaptation in terrestrial environments is to maximize carbon gain while maintaining a favorable plant water status and avoiding hydraulic failure. This requires adjustment of the plant's conducting system to maximize water uptake and to reduce water deficits (Sperry et al. 1998, 2002; Maseda and Fernández 2006). Trees adapt to changes in water availability either with long-term plastic responses in the size of the absorbing root system and in the evaporating leaf surfaces or by modifications in the hydraulic system and adjustment of the cavitation risk along the flow path (Sperry et al. 2002).

The hydraulic system of a tree is composed of a network of vessels that enables the continuous supply of water from roots to shoots. The conductivity of this system is mainly determined by the number, diameter, and length of the vessels along the root-to-leaf flow path. A precise understanding of the hydraulic properties of these conduits is essential for predicting the flow of water in the soil-plantatmosphere continuum because important functions such as the rate of water movement, the maintenance of water potential gradients and the vulnerability to xylem cavitation all are directly related to vessel anatomical characteristics 
and tree hydraulic conductivity (e.g., Wheeler et al. 2005; Cai and Tyree 2010). The hydraulic traits also have a large influence on how the leaf water status of trees is responding to changes in soil water supply and atmospheric water demand (Eamus et al. 2006).

Xylem properties can differ largely among different tree species and also between roots, stem and branches of the same tree (Martínez-Vilalta et al. 2002). It is assumed that about half of a plant's total hydraulic resistance is located belowground, which emphasizes the crucial role played by the root system in water flux control (Passioura 1988; Tyree and Ewers 1991). Surface roots may function like valves in the soil-plant-atmosphere flow path by enabling rapid water transport when the soil is wet, but disconnecting the plant from the driest soil patches through the development of drought-induced embolism (Alder et al. 1996; MartínezVilalta et al. 2002). In agreement with this idea, Sperry and Saliendra (1994) argued that xylem embolism should be easier to reverse in roots than in stems because roots frequently experience positive or near-positive pressures. Furthermore, roots are thought to be cheaper in terms of carbon investment than stems or branches (e.g., Hacke et al. 2000). Unfortunately, we know only very little about the hydraulic properties and anatomy of the xylem in the root systems of mature trees which hinders a better understanding of the functional role of roots in the flow path (Cinnirella et al. 2002; Leuschner et al. 2004). Studies analyzing the withincommunity variation in the hydraulic architecture of plants have mostly focused on the aboveground organs and only few dealt with roots (e.g., Hacke et al. 2000; Martínez-Vilalta et al. 2002; Domec et al. 2004) which makes it difficult to characterize different functional types of roots with specific water absorption and water transport qualities.

We analyzed vessel anatomical properties and measured the axial hydraulic conductivity and apparent embolisminduced reductions in conductivity in small-diameter roots (2-6 $\mathrm{mm}$ in diameter) of five co-occurring temperate broadleaved tree species of the genera Fagus, Acer, Tilia, Carpinus, and Fraxinus that differ in drought tolerance and successional status. Four of the species have a diffuse-porous xylem in the stem while one species (Fraxinus) is ring-porous. According to Ellenberg and Leuschner (2010), Fraxinus excelsior, Carpinus betulus, and Tilia cordata can be classified as drought-tolerant while Fagus sylvatica and Acer pseudoplatanus are more drought-sensitive species. Köcher et al. (2009) ranked the five species in terms of their drought sensitivity in the order Fagus $>$ Acer $>$ Tilia $>$ Carpinus $>$ Fraxinus with the less sensitive species maintaining higher values of pre-dawn leaf water potential, leaf conductance and xylem flux density under restricted water supply. This ranking was confirmed for A. pseudoplatanus, $F$. sylvatica, and $F$. excelsior in a recent study (Scherrer et al. 2011) based on canopy foliage temperature and sap flow data.
We tested the hypotheses that (a) the maximum specific conductivity $\left(k_{\mathrm{s}}\right)$ of roots is a function of conduit diameter, similar as it is in stems, (b) less drought-sensitive tree species produce on average smaller vessels but higher vessel densities in the root xylem than more sensitive species which reduces the risk of embolism in the roots, and (c) the roots of more drought-sensitive species show higher losses of conductivity in summer than those of less sensitive species. We further assumed that the second hypothesis is not valid in the case of ring-porous Fraxinus whose particularly large vessels in the stem were assumed to occur also in the roots, even though the species is known to be rather insensitive to drought.

\section{Materials and methods}

\subsection{Study site and tree selection}

The study was conducted between July and September 2008 in a species-rich temperate broad-leaved forest stand in Hainich National Park in western Thuringia, Central Germany at 350 ma.s.1. $\left(51^{\circ} 05^{\prime} 00^{\prime \prime} \mathrm{N}, 10^{\circ} 30^{\prime} 27^{\prime \prime} \mathrm{E}\right)$. The national park with a size of 7,610 ha is part of one of the largest non-fragmented deciduous woodlands in Central Europe. In the study region, a mixed forest of the StellarioCarpinetum community (oak-hornbeam forest) with $F$. sylvatica L. (European beech), T. cordata Mill. (little-leaf linden), C. betulus L. (European hornbeam), F. excelsior L. (European ash), A. pseudoplatanus L. (sycamore maple) and other broadleaved species is present (Leuschner et al. 2009). The soils are Luvisols developed from loess that overlays Triassic limestone. The mean annual precipitation in the study region is $590 \mathrm{~mm}$ and the mean annual temperature is $7.5^{\circ} \mathrm{C}$ (1973-2004, Weberstedt station, data provided by Deutscher Wetterdienst).

In the studied mixed forest, all five species are present with adult trees in close vicinity to each other and the root systems of the species are broadly overlapping. Thus, we assumed that the trees are exposed to similar edaphic and climatic conditions providing an excellent basis for interspecific comparison. According to Gebauer et al. (2008), tree density varies from 392 to 614 stems ha $^{-1}$ in the study area with a higher mean tree height $(32.9 \mathrm{~m})$ in the less dense patches of the stand as compared to the denser part (27.9 m).

We selected four to six individuals each of $F$. sylvatica, $A$. pseudoplatanus, T. cordata, C. betulus, and F. excelsior with all the sampled trees located within $100 \mathrm{~m}$ from each other (Table 1). We chose trees with representative diameter and height dimensions for the respective species in the stand, i.e., DBH values of 25 to $76 \mathrm{~cm}$ and crowns reaching in the upper canopy layer (height 23-34 m). To access the sun canopies, 
Table 1 Characteristics of the trees selected, mean periderm thickness of root segments, number of root segments used for the hydraulic conductivity measurements (Sperry method) and number of microtome cuts used in the anatomical analysis

\begin{tabular}{lllcccc}
\hline Species & $n$ (trees) & DBH $(\mathrm{cm})$ & Tree height (m) & Periderm thickness (mm) & $n$ (Sperry) & $n$ (anatomy) \\
\hline Fagus sylvatica & 6 & $40.4-60.6$ & $28.2-33.1$ & $0.31 \pm 0.021$ & 71 & 24 \\
Acer pseudoplatanus & 5 & $36.7-75.8$ & $26.8-33.7$ & $0.35 \pm 0.013$ & 59 & 20 \\
Tilia cordata & 4 & $40.6-62.6$ & $24.3-31.7$ & $0.47 \pm 0.030$ & 48 & 59 \\
Carpinus betulus & 5 & $31.7-59.7$ & $24.7-29.2$ & $0.28 \pm 0.024$ & 72 \\
Fraxinus excelsior & 6 & $23.6-40.3$ & $23.0-32.8$ & $0.60 \pm 0.024$ & 24 \\
\hline
\end{tabular}

we used a mobile canopy lift (model DL30, Denka-Lift AS, Denmark).

\subsection{Leaf water potential}

Daily minima of leaf water potential $\left(\Psi_{\mathrm{L}}\right)$ were measured with a Scholander pressure chamber apparatus (M600, PMS Instrument Company, Albany, USA) on three sampling dates between July and September 2008 for assessing indications of drought stress. Four leaf (or shoot) samples per tree and sampling date were investigated in the exposed sun crown of the five species (i.e., 16 to 24 samples per species and occasion). The leaf or shoot samples were measured immediately after sampling. All measurements were conducted between 11:00 and 14:00 when diurnal minima of $\Psi_{\mathrm{L}}$ are typically occurring.

\subsection{Native root hydraulic conductivity and embolism}

Initial and maximum axial hydraulic conductivity of segments of small-diameter roots (2-6 $\mathrm{mm}$ in diameter) were determined empirically following the protocol given by Sperry et al. (1988). Twelve root segments per tree (48-72 per species) were collected on different occasions between July and September 2008 in the topsoil $(0-10 \mathrm{~cm}$ depth). The species identity of the roots was detected by tracing the roots back to the stem or a major root. The mean diameter of the more than 300 sampled roots was $3.31 \pm 0.052$ (SE) $\mathrm{mm}$. The number of samples per species and the size characteristics of the sampled trees are given in Table 1. For avoiding embolism caused by the cutting of the roots, we used only root samples with a minimum length $>15 \mathrm{~cm}$ which presumably exceeded maximum vessel length in the root segments. Immediately after collection, the root samples were stored in polyethylene tubes filled with water containing a sodium-silver chloride complex (Micropur, Katadyn, Wallisellen, Switzerland) to prevent microbial growth and to avoid the development of new emboli. The samples were taken to the laboratory and stored at $4{ }^{\circ} \mathrm{C}$ until measurement which took place within 7 days. We assumed that bubbles enclosed in the vessels and causing cavitation were not dissolved during the period between cutting and measurement because ambient pressure was kept constant (Tyree and Yang 1992). Prior to measurement, each segment was re-cut under water with a razor blade; the length of the root segments used for measurement was at least $6 \mathrm{~cm}$. Measurements of hydraulic conductivity $\left(k_{\mathrm{h}}\right)$ were consecutively conducted at least three times in each root segment according to the specifications made by Sperry et al. (1988). We used de-ionized water containing sodium-silver chloride for the flow measurement. The solution was passed through a 0.2- $\mu \mathrm{m}$ membrane filter (Maxi Capsule, Pall, USA) to prevent blockage of vessels by microscopic particles. The water flow through the root segments was driven by a pressure of about $0.007 \mathrm{MPa}$. Water leaving the distal end of the segment was collected and weighed with an accuracy of $0.1 \mathrm{mg}$. The hydraulic conductivity $\left(k_{\mathrm{h}}\right)$ was then calculated as

$k_{\mathrm{h}}=F \frac{l}{\Delta P}=\frac{\Delta V}{\Delta t} \times \frac{l}{\Delta P}\left[\frac{\mathrm{kg} \mathrm{m}}{\mathrm{MPa} \mathrm{s}}\right]$

where $F$ is the flow rate (in kilograms per second), $l$ the length of the root segment (in meters), $\Delta P$ the pressure difference applied to the segment (in megapascals), $\Delta V$ the amount of water flowing out of the root segment (in kilograms), and $\Delta t$ the time interval of measurement (in seconds). After measuring initial conductivity $\left(k_{\mathrm{h}}\right)$, the segments were flushed with a pressure of $0.12 \mathrm{MPa}$ to remove existing native emboli and to achieve maximum axial conductivity $\left(k_{\max }\right)$ in consecutive measurements. A smaller value of $k_{\mathrm{h}}$ than $k_{\max }$ was interpreted as evidence for the existence of emboli in the flow path and the size of the difference between $k_{\mathrm{h}}$ and $k_{\max }$ was taken as a measure of the percental loss of conductivity (PLC) under in situ conditions ("native" embolism, Alder et al. 1996)

$\mathrm{PLC}=\frac{k_{\max }-k_{\mathrm{h}}}{k_{\max }} \times 100[\%]$

Sapwood area-specific conductivity $\left(k_{\mathrm{s}}\right.$, in $\left.\mathrm{kg} \mathrm{MPa}^{-1} \mathrm{~s}^{-1} \mathrm{~m}^{-1}\right)$ was obtained from $k_{\max }$ or theoretical conductivity $k^{\text {theo }}$ (see 
below) by scaling to the xylem cross-sectional area ( $\left.A_{\text {xylem }}\right)$.

$k_{\mathrm{s}}=\frac{k_{\max }}{A_{\mathrm{xylem}}}\left[\frac{\mathrm{kg}}{\mathrm{MPa} \mathrm{s} \mathrm{m}}\right]$

The xylem cross-sectional area in the roots was either measured directly by anatomical inspection under the microscope (see below) or, in a number of samples, estimated with a regression equation that relates measured root xylem area to root diameter.

\subsection{Root vascular anatomy}

For analyzing root xylem anatomy, we selected by random a third of the root samples used for hydraulic conductivity measurements, cut 5-10-mm-long segments from the proximal end and immersed them in polyethylenglycol (Type 2000, Merck Schuchardt, Hohenbrunn, Germany) for preparation. After hardening, 10-20- $\mu \mathrm{m}$-thick disks were cut with a sliding microtome (Hn 40, Reichert Jung, Nussloch, Germany), mounted on microscope plates and submersed in Euparal (Chroma, Muenster, Germany). Finally, the disks were oven-dried for a week at $50^{\circ} \mathrm{C}$.

Photographs of the cross-sectional cuts were taken with a digital camera (PowerShot A620, Canon, Japan) mounted on a light microscope (Photomikroskop III, Zeiss, Jena, Germany). An object micrometer with a resolution of $10 \mu \mathrm{m}$ was used as scale reference. If the area of the root sample was too large for a single image, several pictures were taken and they were subsequently re-arranged using Adobe Illustrator CS2 (Version 12.0.1, Adobe Systems Incorporated, USA) prior to the digital analyses. The images were analyzed with the software Image J (v1.36b, http://rsb. info.nih.gov/ij) using the particle analysis-function for estimating the idealized radius $(r)$ of the vessels by means of lumen area $\left(A=\pi r^{2}\right)$, vessel density (in number per square millimeters) and cumulative cross-sectional area of all vessels (in square meters). The xylem area ( $A_{\mathrm{xylem}}$, in square meters) in the root cross-section was determined by subtracting the bark and parenchymatic tissue from the total cross-sectional area. Since the analysis of xylem anatomy and vessel dimensions is very labor-intensive, we investigated only every third of the conductivity samples (Table 1).

The movement of water in xylem vessels can be described in a first approximation by Hagen-Poiseuille's law. This equation can thus be used to calculate the ideal theoretical hydraulic conductivity of a root segment from the radii of its vessel elements,

$k^{\text {theo }}=\frac{\pi \sum r^{4}}{8 \eta}\left[\frac{\mathrm{m}^{4}}{\mathrm{MPa} \mathrm{s}}\right]$

where $r$ is the radius of a vessel and $\eta$ the viscosity of pure water $\left(1.002 \times 10^{-3} \mathrm{~Pa}\right.$ s at $\left.20^{\circ} \mathrm{C}\right)$. The theoretical conductivity $k^{\text {theo }}$ was then multiplied with the density of water $(\rho)$ at $20^{\circ} \mathrm{C}$ (998.20 $\mathrm{kg} \mathrm{m}^{-3}$ ) to achieve consistency of units.

2.5 Soil water content and soil matrix potential

Volumetric soil water content $(\Theta$, in cubic meters per cubic meter) was measured with time domain reflectometry sensors (CS616 Water Content Reflectometer, Campbell Scientific Ltd., Cambridge, UK) installed at three different depths (10, 30 and $50 \mathrm{~cm}$ ) in close proximity to the studied trees. Two measurements were taken per day $(0: 00 \mathrm{~h}$ and 12:00 h). We used the water content data from $10 \mathrm{~cm}$ soil depth for analysis because the root samples originated from this depth $(0$ $10 \mathrm{~cm})$. The TDR sensors at lower depths were used for monitoring the depletion of soil water in the profile.

Soil matrix potential $\left(\Psi_{\mathrm{S}}\right)$ was estimated with the program Rosetta Version 1.2 (Schaap et al. 1998) from the soil water content data. This program implements pedotransfer functions to predict water retention parameters after van Genuchten (1980) based on soil bulk density and textural distribution. The calculated parameters were used in the van Genuchten water retention function to derive soil matrix potential $\left(\Psi_{\mathrm{S}}\right)$. The required soil physical parameters (e.g., clay content, bulk density) were provided by Guckland et al. (2009).

\subsection{Statistical analyses}

Basic statistics (arithmetic mean or median, standard error) were calculated with Microsoft Office Excel 2003 software. Regression analyses were conducted with the program Xact $7.20 \mathrm{~g}$ (SciLab GmbH, Hamburg, Germany). All other statistical calculations were done with SAS software, version 9.1 (SAS Institute Inc., Cary, NC, USA). To examine differences between tree species in anatomical properties and hydraulic conductivity, the data sets were first tested for normal distribution with a Shapiro and Wilk test. The assumption of normal distribution was not met in all cases. In non-normally distributed data sets, we conducted pair-wise comparisons of hydraulic trait means among the five species with the Wilcoxon $U$ test after Mann and Whitney. Otherwise, we performed a one-way analysis of variance using the general linear model procedure followed by Tukey's test. The tests for comparing means were chosen according to the structure (balanced/imbalanced) of the data sets (see Table 1).

\section{Results}

3.1 Precipitation and soil water content

The study region received in 2008 slightly more precipitation $(652 \mathrm{~mm})$ than the long-term average $(590 \mathrm{~mm})$. Nevertheless, 
the vegetation period from May to October was relatively dry. Especially in the study period between July and September, the precipitation total was $44 \%$ lower than the average for these months as derived from measurements in the years 2000-2007 (40 $\mathrm{mm}$ in 2008 vs. $72 \mathrm{~mm}$ in 2000-2007).

The volumetric soil water content $(\Theta)$ at $10 \mathrm{~cm}$ depth was significantly lower than that at 30 and $50 \mathrm{~cm}$ throughout the summer. At all three depths, $\Theta$ decreased progressively from May to mid-September. The lowest soil water content was recorded in September at $10 \mathrm{~cm}$ depth $\left(0.163 \mathrm{~m}^{3} \mathrm{~m}^{-3}\right)$. The soil matrix potential $\left(\Psi_{\mathrm{S}}\right)$ in $10 \mathrm{~cm}$ depth varied between $-0.09 \mathrm{MPa}$ (July) and $-0.24 \mathrm{MPa}$ (September) in the study period.

\subsection{Leaf water potential}

The means of midday leaf water potential $\left(\Psi_{\mathrm{L}}\right)$ recorded in summer 2008 differed significantly among the five species with by far highest values in Acer ( $-0.4 \mathrm{MPa})$ and lowest in Fagus (-2.3 MPa), while Fraxinus, Carpinus, and Tilia showed intermediate $\Psi_{\mathrm{L}}$ means $(-2.2,-2.0$, and $-1.6 \mathrm{MPa}$, respectively). The midday means of $\Psi_{\mathrm{L}}$ decreased significantly with a decline in soil matrix potential in Acer, Fagus, and Carpinus, while they were independent from soil matrix potential in Tilia and Fraxinus (Fig. 1). In Tilia, however, a tendency for a decrease in $\Psi_{\mathrm{L}}$ with decreasing $\Psi_{\mathrm{S}}$ was visible. In the only ring-porous species, Fraxinus, $\Psi_{\mathrm{L}}$ was highly variable during mid-summer without a clear relationship to soil matrix potential.

\subsection{Root vascular anatomy}

The small-diameter roots of the five species with $2-6 \mathrm{~mm}$ in diameter showed significant differences in the proportion of

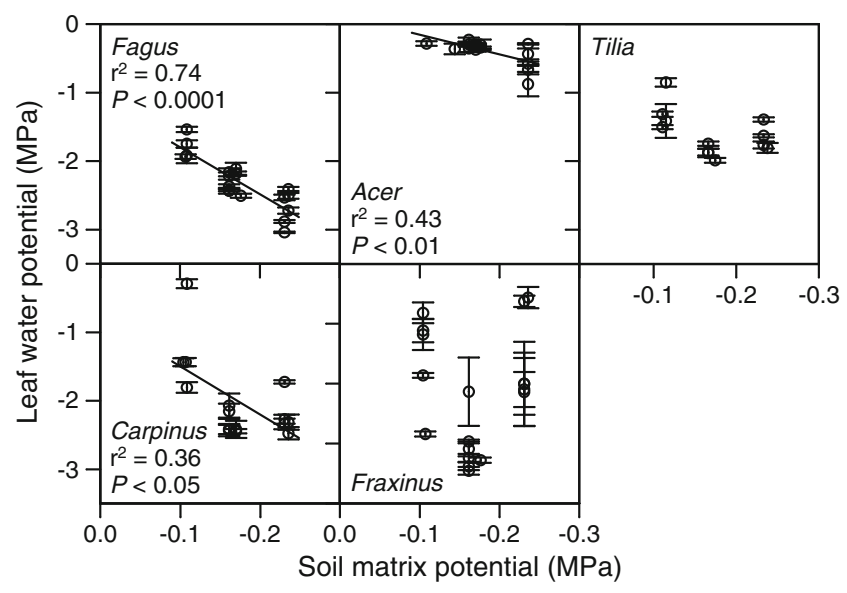

Fig. 1 Daily means of midday leaf water potential $\Psi_{\mathrm{L}}$ in relation to the soil matrix potential $\Psi_{\mathrm{S}}$ at $10 \mathrm{~cm}$ depth in the five examined tree species in summer 2008. Number of replicates: four to six trees per species with four samples per tree. For significant relationships, the coefficient of determination $\left(r^{2}\right)$ and the $P$ value is given the root xylem cross-sectional area that was occupied by vessel lumina (Table 2). Tilia and Fagus roots had significantly larger relative vessel lumen areas in the xylem cross-section than Acer and Carpinus (17-18 vs. 10-11\%); the smallest cumulative lumen area was detected in Fraxinus roots (6\%). The same species sequence was observed for vessel density with highest densities produced by Tilia roots (mean: 118 vessels $\mathrm{mm}^{-2}$ ) and lowest by Fraxinus $\left(53 \mathrm{~mm}^{-2}\right.$, Table 2$)$.

All five species showed a considerable variation in vessel diameters $(d)$ in the root xylem $(<20$ to $>100 \mu \mathrm{m}$, Table 2 and Fig. 2). Small vessels with a mean $d$ of $20-25 \mu \mathrm{m}$ were the most frequent size class in the xylem of Fraxinus, Acer, Tilia, and Carpinus roots while in Fagus, the most frequent size class had a larger mean diameter $(30-35 \mu \mathrm{m})$. The species with largest mean vessel diameters (Fagus and Tilia) differed significantly from the ring-porous species Fraxinus with smallest mean $d$, while Fagus, Tilia, Carpinus, and Acer differed not significantly from each other $(29-32 \mu \mathrm{m}$, Table 2). In all species, $d$ showed a left-skewed distribution, but the vessel number decrease toward larger diameter classes was steeper in the xylem of Fraxinus roots (Fig. 2) with smallest mean $d$ (Table 2). In this species, $26 \%$ of all vessels referred to conduits with diameters of $20-25 \mu \mathrm{m}$. In all five species, we observed a small number of very large vessels with $d>80 \mu \mathrm{m}$ and maxima even exceeding $100 \mu \mathrm{m}$. The largest conduit was measured in a root segment of Carpinus $(115 \mu \mathrm{m})$.

The roots of the five species also differed in mean thickness of the root bark with the thickest periderm observed in Fraxinus (mean, $0.60 \mathrm{~mm}$ ) and Tilia $(0.47 \mathrm{~mm}$ ) and the thinnest in Carpinus and Fagus (0.28 and $0.31 \mathrm{~mm}$, Table 1). Consequently, the xylem occupied a significantly smaller area of the root cross-section in Fraxinus and Tilia (42\% and $48 \%)$ than in the other species (58-66\%, Table 2). Further, the species with a thinner periderm showed a steeper increase of the relative xylem area in the root cross-section with increasing root diameter than the species with thicker periderm; the mean slope $b$ of the xylem area/root crosssection relationship was $0.78,0.79$ and 0.74 in Fagus, Carpinus and Acer but only 0.50 and 0.51 in Fraxinus and Tilia (data not shown). Thus, larger Fraxinus and Tilia roots had a relatively small xylem area in comparison to the other species. The pith area in the root cross-sections was small in all species $(<1 \%)$ and its neglect in the calculation did not alter the relationship between xylem area and root crosssectional area in a significant manner in any of the species. However, thicker roots $(>3.5 \mathrm{~mm}$ in diameter $)$ were characterized by a larger proportion of pith ray tissue in the cross-section than smaller ones.

\subsection{Hydraulic conductivity and embolism}

The empirically determined specific conductivity of the roots $\left(k_{\mathrm{s}}\right)$ differed more than threefold in its mean between 


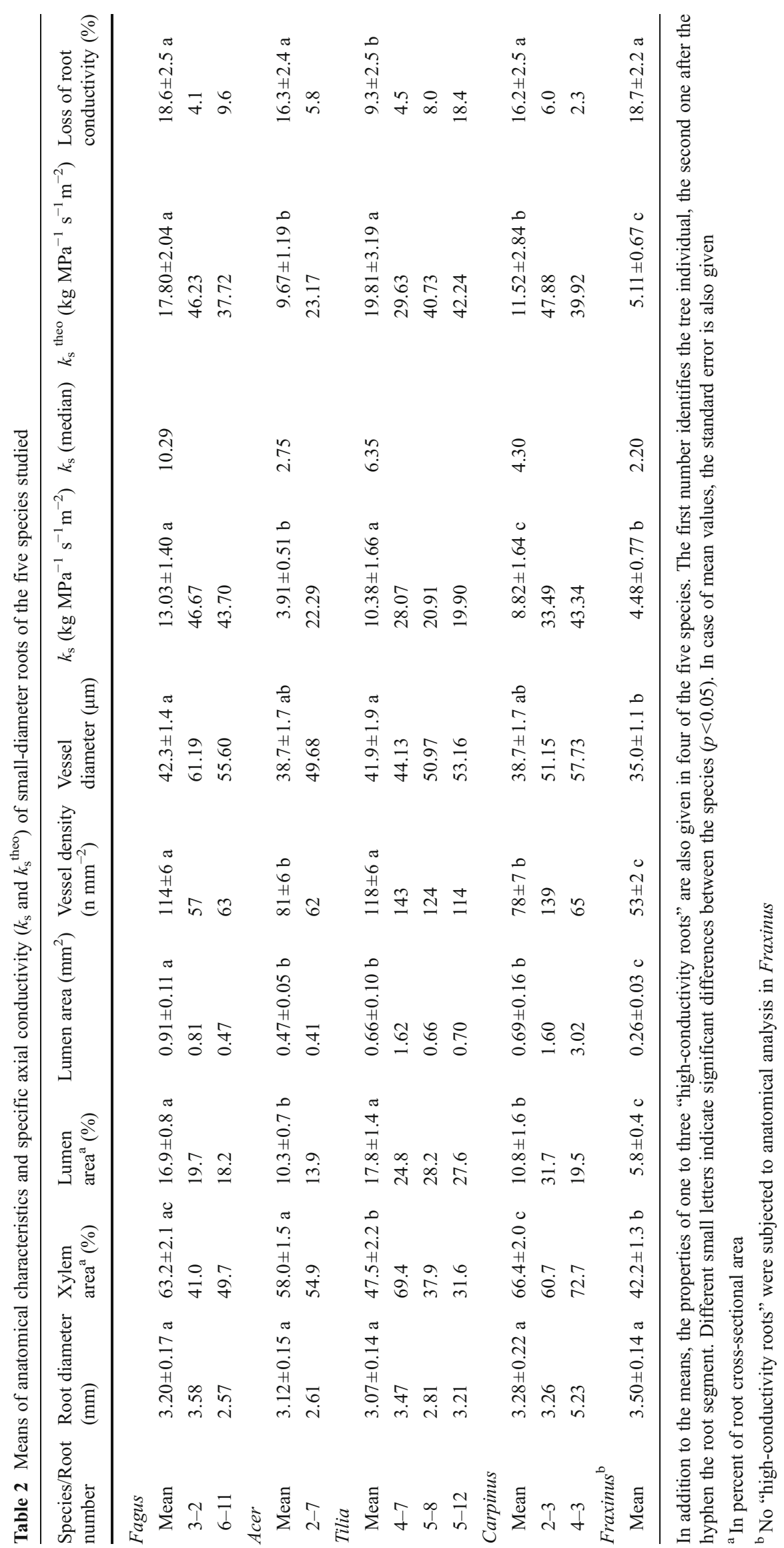




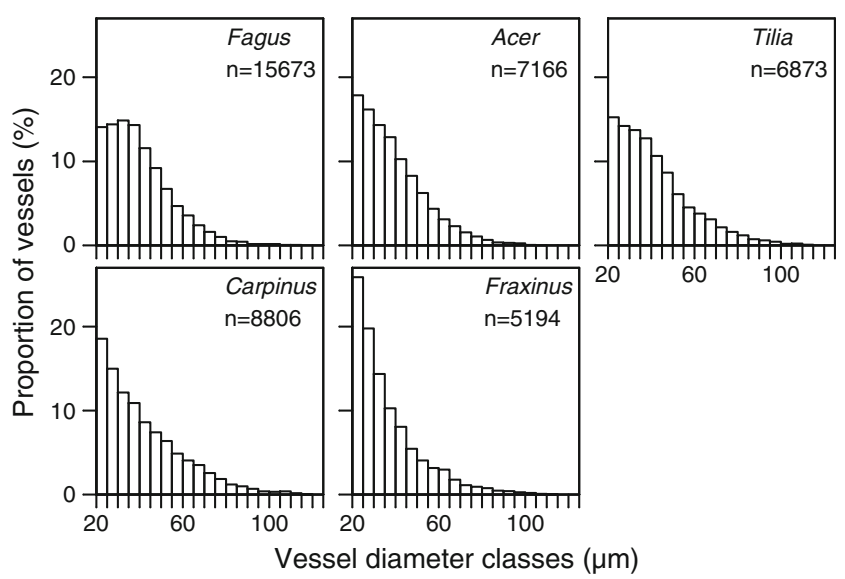

Fig. 2 Relative abundance of vessels in different diameter classes (class width $=5 \mu \mathrm{m}$ ) in the xylem of small-diameter roots of the five tree species. $n$ number of all vessels measured per species (for the number of roots examined see Table 1)

the species. It was highest in Fagus, Carpinus, and Tilia roots (means of 8.8-13.0 $\mathrm{kg} \mathrm{MPa}^{-1} \mathrm{~s}^{-1} \mathrm{~m}^{-2}$ ) and significantly smaller in Acer and Fraxinus roots (3.9 and $4.5 \mathrm{~kg} \mathrm{MPa}^{-1} \mathrm{~s}^{-1} \mathrm{~m}^{-2}$, Table 2). The median values of $k_{\mathrm{s}}$ showed a slightly different picture than the means with lower values especially in Carpinus and Fraxinus (Table 2). Root-specific conductivity varied by more than a magnitude among the 48-72 roots examined per species with the variation apparently being larger in Fagus, Tilia, and Carpinus roots than in Acer and Fraxinus roots (Fig. 3).

In all five species, a few roots had $k_{\mathrm{s}}$ values that exceeded the specific conductivity medians of the species four- to tenfold or even more; these roots were termed "high-conductivity roots" (Table 2 and Fig. 3). While these roots did not differ from the respective population mean in terms of

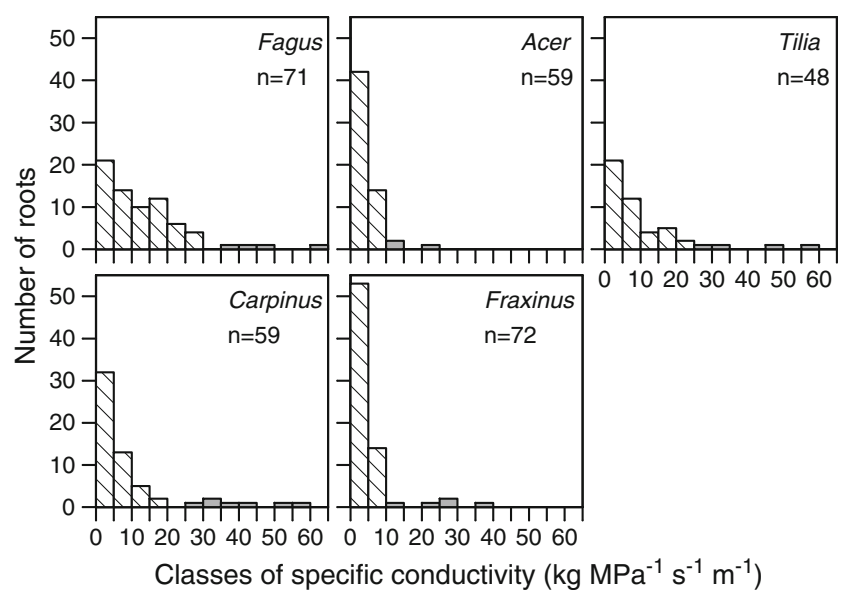

Fig. 3 Number of roots in classes of root-specific conductivity $k_{\mathrm{s}}$ (class width $=5 \mathrm{~kg} \mathrm{MPa}^{-1} \mathrm{~s}^{-1} \mathrm{~m}^{-1}$ ) in the five tree species. Gray bars indicate roots which were considered to be "high-conductivity roots". $n$ number of roots examined per species root diameter and xylem area in the cross-section, they were characterized by considerably larger mean vessel diameters, in certain cases also by higher vessel densities (Table 2).

The theoretical specific conductivity as derived from the vessel diameters $\left(k_{\mathrm{s}}^{\text {theo }}\right)$ was in all species except for Fraxinus significantly higher than the empirically determined $k_{\mathrm{s}}$ (difference not significant in Fraxinus). The mean $k_{\mathrm{s}}$ values reached only $40.4 \%$ and $52.4 \%$ of the respective $k_{\mathrm{s}}^{\text {theo }}$ means in Acer and Tilia, respectively, compared to $73.2 \%$, $76.5 \%$, and $87.6 \%$ in Fagus, Carpinus and Fraxinus (Table 2).

Repeated conductivity measurements after Sperry et al. (1988) conducted in 48-72 roots per species in summer 2008 indicated that Fagus, Fraxinus, Acer, and Carpinus roots experienced conductivity losses (PLC) in the range of $16.2-17.8 \%$ in this period which were attributed to xylem embolism; the PLC mean of Tilia roots was significantly smaller (9.3\%, Table 2). In Fagus and Fraxinus roots, the conductivity loss increased with a seasonal decrease in soil matrix potential while no dependence of PLC on $\Psi_{\mathrm{S}}$ was detected for the other three species (Fig. 4). Surprisingly, roots with larger mean vessel diameters generally showed smaller conductivity losses than roots with thinner vessels (Fig. 5: right). Such a negative relationship was detected in Fagus, Acer, Carpinus, and Fraxinus roots but was not present in Tilia roots. We found no dependency of PLC on vessel density in the species (data not shown).

As expected, all species showed a positive relation between mean vessel diameter and $k_{\mathrm{s}}$, but the slope of the relation differed between the species (Fig. 5: left; steepest slope in Fagus, lowest slope in Fraxinus). Vessel density had no influence on $k_{\mathrm{s}}$ in the five species (data not shown).

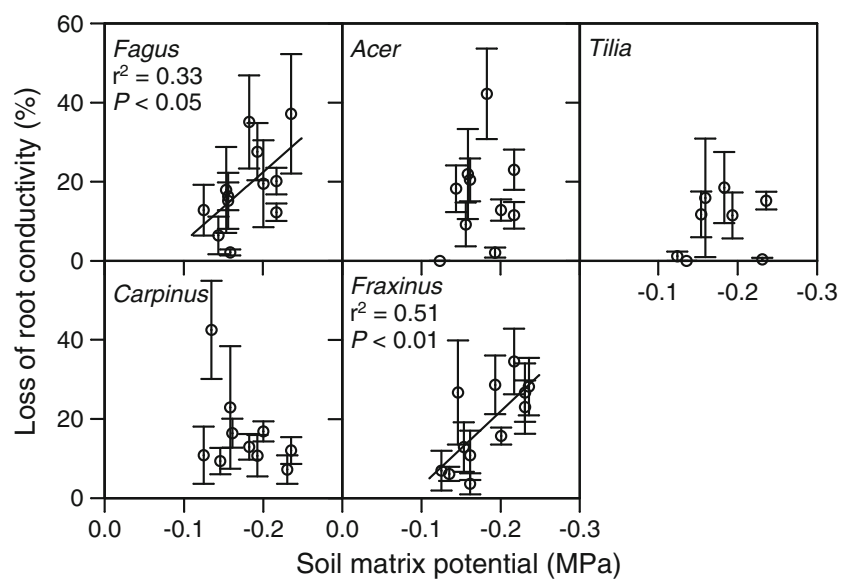

Fig. 4 Percental loss of conductivity (PLC) in the xylem of smalldiameter roots in relation to the soil matrix potential $\Psi_{\mathrm{S}}$ at $10 \mathrm{~cm}$ depth in the five examined tree species in summer 2008. Number of replicates: four to six trees per species with six samples per tree. For significant relationships, the coefficient of determination $\left(r^{2}\right)$ and the $P$ value are given 


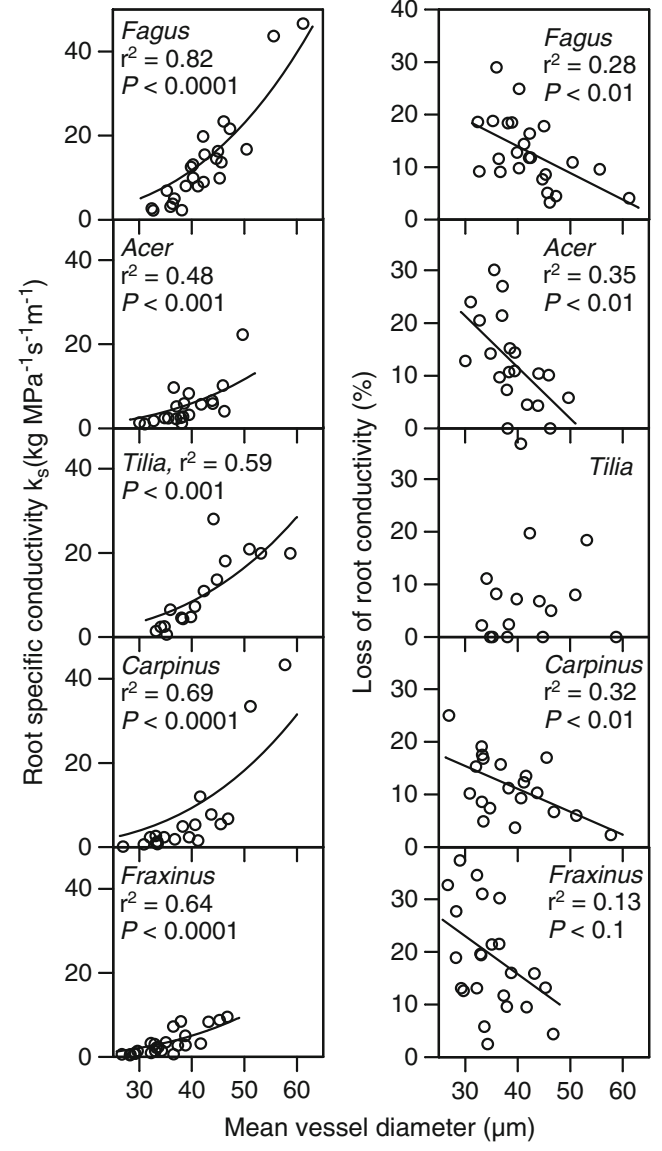

Fig. 5 Dependence of root-specific conductivity $k_{\mathrm{s}}$ (left) and the percental loss of conductivity (PLC) (right) on mean vessel diameter in small-diameter roots of the five species. Number of replicates: four to six trees per species with each four samples per tree. For significant relationships, the coefficient of determination $\left(r^{2}\right)$ and the $P$ value are given

A plot of the species means of root $k_{\mathrm{s}}$ against the cumulative surface area of the fine root system of the five species (root area index, RAI, in square meters surface area per square meter ground area) showed no relationship (Fig. 6a). Similarly, no dependence of $k_{\mathrm{s}}$ on the fine root biomass of the respective species in the soil profile to $40 \mathrm{~cm}$ depth was found (Fig. 6b).

\section{Discussion}

4.1 Relationship between root anatomy and hydraulic conductivity

The first hypothesis of our study regarding the positive relation between root axial hydraulic conductivity and vessel diameter was confirmed for all five species. Mean vessel diameter $d$ was the main determinant of root-specific conductivity and $k_{\mathrm{s}}$ increased exponentially with increasing $d$,

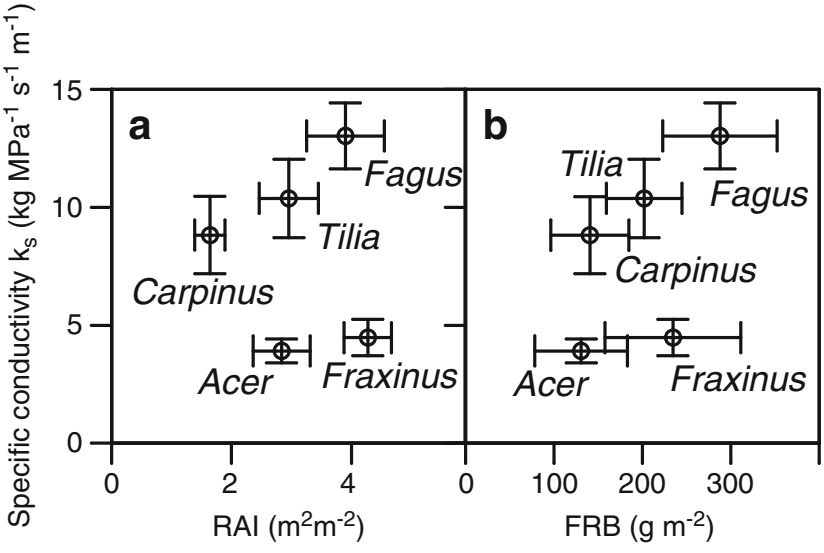

Fig. 6 Empirically determined specific conductivity $k_{\mathrm{s}}$ of the xylem of small-diameter roots in relation to the root area index RAI (a) and the fine root biomass FRB in 0-20 cm (b) of the species in monospecific patches. Data of root area index and fine root biomass are means of four monospecific plots per species, studied by Jacob et al. (submitted)

but the slope differed between the species. We found no dependence of $k_{\mathrm{s}}$ on vessel density in the root xylem which is contrary to the results reported by Tyree and Ewers (1991), Cruiziat et al. (2002) and Tyree and Zimmermann (2002) for the hydraulic system in trunk and branches. The lack of a vessel density effect in our study can partly be explained by the negative relation between mean vessel diameter and vessel density in the roots of three of the five species (Fagus, Acer, and Tilia; data not shown).

The five investigated species differed markedly in rootspecific conductivity due to species differences in mean vessel diameter and also in the relative size of the xylem area in the root (Table 2). The small-diameter roots of Fagus had on average a three times larger empirically determined $k_{\mathrm{S}}$ than Fraxinus roots, even though they were collected in the same soil volume. For theoretical specific conductivity $\left(k_{\mathrm{s}}^{\text {theo }}\right)$, the species differences were even larger.

From earlier studies in the Hainich forest on leaf water status and stomatal regulation in mature trees of the five species, we had expected that the more drought-tolerant species should possess smaller mean vessel diameters in the roots than the more sensitive ones in order to avoid root embolism. Tolerant Fraxinus indeed had relatively small and sensitive Fagus large vessel diameters, but the other three species differed only little with respect to $d$ and $k_{\mathrm{s}}$. This invariance in $k_{\mathrm{s}}$ partly matches with only relatively small differences in reported drought sensitivity of the three species at the shoot level (Köcher et al. 2009).

Contrary to our expectation, we observed no ring-porous xylem anatomy in the roots of Fraxinus which characterizes the stem xylem. This species with small conduits in the root xylem and large vessels in the ring-porous stem xylem is evidence for the fact that xylem anatomy can be highly variable along the flow path within a tree. The small conduits in 
the roots may illustrate the functional role fine roots probably are playing in reducing the embolism risk in proximity to the organs of plant water uptake.

Several factors should determine how much axial conductivity is developed in the xylem of a root, including the water availability in the explored soil volume, the water demand of the canopy and root biomass (or the total crosssectional area of the root system). A hint on inter-relationships between root hydraulic properties, total root mass, and tree water consumption can be drawn from Fig. 6. Fraxinus with a relatively small leaf area index compared to the other cooccurring species (Hölscher 2004) produced roots with a small axial conductivity but maintained a relatively large fine root biomass. In contrast, the fine root biomass of Fagus was not different from that of Fraxinus but was linked to a much higher root conductivity which meets a higher leaf area index and therefore an elevated demand for water in the canopy. In this comparison, Carpinus and Tilia take an intermediate position, while the low root axial conductivity of Acer in combination with a relatively small fine root biomass was possibly balanced by a small variation in leaf water potential and effective leaf conductance regulation.

However, the available data on root mass and water consumption are not sufficient to conclude on the possible interplay of root morphology, physiology, and whole-tree water use in this forest.

\subsection{Species differences in apparent root embolism}

We estimated the degree of native embolism in the root xylem on several dates in late summer under a range of soil matrix potentials in the topsoil varying between -0.09 and $-0.24 \mathrm{MPa}$. From the c. $60-70$ measurements per species, we obtained several results that do not fit into the existing picture of xylem embolism in broad-leaved trees and its assumed control by biotic and abiotic factors.

First, the observed soil moisture dependence of root embolism was remarkably small. Only two of the five species (Fagus and Fraxinus) showed the expected increase in the percental loss of conductivity with decreasing soil matrix potential while the other three species developed conductivity losses up to $45 \%$ in apparent independence from soil moisture availability.

A possible explanation for the lacking relationship between apparent root embolism and soil moisture in some species is rapid embolism repair under elevated root water potentials during the night (Zwieniecki and Holbrook 1998) which might decouple the embolism status from the soil moisture regime. In fact, measurements in Fraxinus, Carpinus, and Acer trees in summer 2006 showed that the predawn leaf water potential $\left(\Psi_{\mathrm{pd}}\right)$ remained favorable in these species even in dry spells (Köcher et al. 2009) indicating that the root water potential may have been high enough to allow for continuous embolism reversal during the summer. However, embolism repair should be more problematic in larger vessels since the minimum pressure required for dissolving air bubbles in the xylem fluid increases with conduit diameter according to Henry's law (Tyree and Yang 1992). Fagus had not only the largest mean vessel diameter in its roots but also showed a larger decrease in $\Psi_{\mathrm{pd}}$ and in the daily leaf water potential minima during summer drought than the other species (Köcher et al. 2009) which must further complicate embolism repair in the roots of this species. These hydraulic characteristics may explain why the PLC values increased with a decrease in soil matrix potential in Fagus. A possible alternative explanation for the lacking PLC - soil moisture relation in three species could be the rather mild drought stress experienced in summer 2008 (soil water potential minima of only $-0.24 \mathrm{MPa}$ in the study period) which might have been too low to induce root embolism. However, Rewald (2008) measured PLC 50 values in small-diameter roots (1-3 mm) of Fagus of $-0.4 \mathrm{MPa}$ (air pressure applied) which is much higher (less negative) than PLC $_{50}$ values reported in the shoots of Fagus (-2 MPa, Cochard et al. 1999) indicating a higher cavitation sensitivity of fine roots. Thus, it is likely that soil water potentials of $-0.24 \mathrm{MPa}$ were low enough to induce a certain degree of embolism in Fagus roots.

Second, the significant negative relationship between vessel size and embolism observed in this study contradicts the findings reported in the literature that species with wider vessels tend to be more vulnerable to cavitation (e.g., Hargrave et al. 1994; Cai and Tyree 2010). Fraxinus roots showed the largest measured conductivity losses of all species (on average by 19\%) despite small vessel diameters. In this species, the loss of root conductivity may have been compensated by the species' relatively large fine root biomass enabling Fraxinus to tolerate large leaf water potential amplitudes while maintaining constant sap flow rates even in dry summer periods (Köcher et al. 2009). However, recent studies (e.g., Christman et al. 2009; Lens et al. 2011) produced evidence that the xylem vulnerability to cavitation may be more closely related to the inter-vessel pit structure than to vessel diameter. Already Zimmermann (1983) assumed that the vulnerability to cavitation caused by air-seeding is primarily dependent on the properties of the inter-vessel walls and their pits and the resulting capability of restricting the mass flow from one cell to another. Accordingly, it has been estimated that half of the total flow resistance in the vessel network is located along the path through the intervessel pits (Wheeler et al. 2005; Choat et al. 2008). These results underpin the need of investigating the microscopic pit structure of the vessels for fully understanding the physical basis of the hydraulic architecture of trees. 


\subsection{Evidence for the existence of high-conductivity roots}

The marked left-skewed frequency distribution of the roots in terms of their specific conductivity with a few "high-conductivity roots" is a pattern that has already been observed in other root hydraulic studies with broad-leaved trees. For example, Rewald (2008) identified high-conductivity roots in mature $F$. sylvatica and Quercus petraea trees with up to 10-times higher $k_{\mathrm{s}}$ values than the mean. In agreement with this observation, Leuschner et al. (2004) found for Fagus, Quercus, and Picea trees a very large variability in the simultaneously measured water flow rates in different small-diameter roots of the same species. Our anatomical data show that trees can achieve high conductivities either by producing a few very large vessels (as in Fagus and Acer), by increasing vessel density (as in Tilia), or by combining both strategies (as in Carpinus). The large root morphological and functional plasticity is, at least in part, a response to the high heterogeneity of moisture in soils, in particular in those exposed to periodic drought (Göttlein and Manderscheid 1998). Roots or root branches are acting as physiologically autonomous units (Shani et al. 1993) that tend to optimize the cost/benefit ratio of root operation under variable water availabilities. In our study, all roots investigated for $k_{\mathrm{s}}$ were sampled in the topsoil at $0-10 \mathrm{~cm}$ depth and thus, the differences in $k_{\mathrm{s}}$ cannot be attributed to contrasting moisture regimes in different soil layers (see, for example, Pate et al. 1995). However, the surprising negative relationship between vessel size and percental loss of conductivity (Fig. 5) may perhaps indicate that the trees had produced roots with particularly high conductivity mainly in topsoil patches with ample water availability. If valid, the water uptake of the root system would be optimized at a low risk of drought-induced cavitation. Further research on the location of high conductivity roots in soil patches of different soil moisture will be needed to test this hypothesis.

\subsection{Conclusions}

The five broad-leaved tree species of this study showed significant anatomical differences in their small-diameter roots that could partly be related to the assumed drought tolerance of the species with more drought-sensitive trees generally having larger mean vessel diameters in their roots than tolerant species. Ring-porous Fraxinus as the probably most drought-tolerant species of the species sample produced a root xylem with smallest mean $d$ and relatively low vessel density. The resulting low specific conductivity of the roots may perhaps be related to the relatively low canopy transpiration of this species; while in Fagus with a relatively high water consumption, large vessels were found. However, the small-vessel diameters of Fraxinus were not found to be advantageous with respect to the risk of root embolism, because the measured apparent "native" root embolism did not show the expected dependence on mean $d$ among the five species.

By investigating many roots of the same species, we found a large intraspecific variability in axial conductivity of roots of similar diameter, and all species produced "highconductivity roots" with $k_{\mathrm{s}}$ values exceeding the median by factors of four to ten or more. We conclude that (1) the hydraulic properties of small-diameter roots differ markedly between coexisting temperate broad-leaved tree species, (2) the functional properties of the root xylem cannot be inferred from the properties of the stem xylem, and (3) vessel diameter is the principal determinant of root axial specific conductivity but apparently not a good predictor of cavitation risk.

Acknowledgments We would like to thank the Hainich National Park administration for the good cooperation and the permit to work in the forest. We also thank Nicolai Brock for giving advice in technical details of the measurement of hydraulic conductivity in tree roots.

Funding This study was conducted within the framework of "Graduiertenkolleg 1086" with funding received by the German Research Foundation (DFG).

Open Access This article is distributed under the terms of the Creative Commons Attribution License which permits any use, distribution, and reproduction in any medium, provided the original author(s) and the source are credited.

\section{References}

Alder N, Sperry J, Pockman W (1996) Root and stem xylem embolism, stomatal conductance, and leaf turgor in Acer grandidentatum populations along a soil moisture gradient. Oecologia 105:293-301

Cai J, Tyree MT (2010) The impact of vessel size on vulnerability curves: data and models for within-species variability in saplings of aspen, Populus tremuloides Michx. Plant Cell Environ 33:1059-1069

Choat B, Cobb AR, Jansen S (2008) Structure and function of bordered pits: new discoveries and impacts on whole-plant hydraulic function. New Phytol 177:608-626

Christman MA, Sperry JS, Adler FR (2009) Testing the 'rare pit' hypothesis for xylem cavitation resistance in three species of Acer. New Phytol 182:664-674

Cinnirella S, Magnani F, Saracino A, Borghetti M (2002) Response of a mature Pinus laricio plantation to a three-year restriction of water supply: structural and functional acclimation to drought. Tree Physiol 22:21-30

Cochard H, Lemoine D, Dreyer E (1999) The effects of acclimation to sunlight on the xylem vulnerability to embolism in Fagus sylvatica L. Plant Cell Environ 2:101-108

Cruiziat P, Cochard H, Améglio T (2002) Hydraulic architecture of trees: main concepts and results. Ann For Sci 59:723-752

Domec JC, Warren JM, Meinzer FC, Brooks JR, Coulombe R (2004) Native root xylem embolism and stomatal closure in stands of Douglas-fir and ponderosa pine: mitigation by hydraulic redistribution. Oecologia 141:7-16

Eamus D, Hatton T, Cook P, Colvin C (2006) Ecohydrology: vegetation function, water and resource management. CSIRO, Collingwood 
Ellenberg H, Leuschner C (2010) Vegetation Mitteleuropas mit den Alpen in ökologischer, dynamischer und historischer Sicht, 6th edn. Ulmer, Stuttgart

Gebauer T, Horna V, Leuschner C (2008) Variability in radial sap flux density patterns and sapwood area among seven co-occurring temperate broad-leaved tree species. Tree Physiol 28:1821-1830

Göttlein A, Manderscheid B (1998) Spatial heterogeneity and temporal dynamics of soil water tension in a mature Norway spruce stand. Hydrol Process 12:417-428

Guckland A, Jacob M, Flessa H, Thomas FM, Leuschner C (2009) Acidity, nutrient stocks, and organic-matter content in soils of a temperate deciduous forest with different abundance of European beech (Fagus sylvatica L.). J Plant Nutr Soil Sci 172:500-511

Hacke UG, Sperry JS, Pittermann J (2000) Drought experience and cavitation resistance in six shrubs from the Great Basin, Utah. Basic Appl Ecol 1:31-41

Hargrave K, Kolb K, Ewers F, Davis S (1994) Conduit diameter and drought-induced embolism in Salvia mellifera Greene (Labiatae). New Phytol 126:695-705

Hölscher D (2004) Leaf traits and photosynthetic parameters of saplings and adult trees of co-existing species in a temperate broad-leaved forest. Basic Appl Ecol 5:163-172

Köcher P, Gebauer T, Horna V, Leuschner C (2009) Leaf water status and stem xylem flux in relation to soil drought in five temperate broad-leaved tree species with contrasting water use strategies. Ann For Sci 66:101

Lens F, Sperry JS, Christman MA, Choat B, Rabaey D, Jansen S (2011) Testing hypotheses that link wood anatomy to cavitation resistance and hydraulic conductivity in the genus Acer. New Phytol 190:709-723

Leuschner C, Coners H, Icke R (2004) In situ measurement of water absorption by fine roots of three temperate trees: species differences and differential activity of superficial and deep roots. Tree Physiol 24:1359-1367

Leuschner C, Jungkunst HF, Fleck S (2009) Functional role of forest diversity: pros and cons of synthetic stands and across-site comparisons in established forests. Basic Appl Ecol 10:1-9

Martínez-Vilalta J, Prat E, Oliveras I, Piñol J (2002) Xylem hydraulic properties of roots and stems of nine Mediterranean woody species. Oecologia 133:19-29

Maseda PH, Fernández RJ (2006) Stay wet or else: three ways in which plants can adjust hydraulically to their environment. J Exp Bot 57:3963-3977

Passioura J (1988) Water transport in and to roots. Annu Rev Plant Phys 39:245-265
Pate JS, Jeschke WD, Aylward MJ (1995) Hydraulic architecture and xylem structure of the dimorphic root systems of South-West Australian species of Proteaceae. J Exp Bot 46:907-915

Rewald B (2008) Impact of climate change-induced drought on tree root hydraulic properties and competition belowground. $\mathrm{PhD}$ thesis, University of Göttingen, Germany.

Schaap MG, Leij FJ, van Genuchten MT (1998) Neural network analysis for hierarchical prediction of soil hydraulic properties. Soil Sci Soc Am J 62:847-855

Scherrer D, Bader MKF, Körner C (2011) Drought-sensitivity ranking of deciduous tree species based on thermal imaging of forest canopies. Agr For Meteorol 151:1632-1640

Shani U, Waisel Y, Eshel A, Xue S, Ziv G (1993) Responses to salinity of grapevine plants with split root systems. New Phytol 124:695-701

Sperry JS, Saliendra NZ (1994) Intra- and inter-plant variation in xylem cavitation in Betula occidentalis. Plant Cell Environ 17:1233-1241

Sperry JS, Donnelly JR, Tyree MT (1988) A method for measuring hydraulic conductivity and embolism in xylem. Plant Cell Environ 11:35-40

Sperry JS, Adler FR, Campbell GS, Comstock JP (1998) Limitation of plant water use by rhizosphere and xylem conductance: results from a model. Plant Cell Environ 21:347-359

Sperry JS, Hacke UG, Oren R, Comstock JP (2002) Water deficits and hydraulic limits to leaf water supply. Plant Cell Environ 25:251263

Tyree MT, Ewers FW (1991) The hydraulic architecture of trees and other woody plants. New Phytol 119:345-360

Tyree MT, Yang S (1992) Hydraulic conductivity recovery versus water pressure in xylem of Acer saccharum. Plant Physiol 100:669-676

Tyree MT, Zimmermann MH (2002) Xylem structure and the ascent of sap. Springer, Berlin

van Genuchten MT (1980) A closed-form equation for predicting the hydraulic conductivity of unsaturated soils. Soil Sci Soc Am J 44:892-898

Wheeler JK, Sperry JS, Hacke UG, Hoang N (2005) Inter-vessel pitting and cavitation in woody Rosaceae and other vesselled plants: a basis for a safety versus efficiency trade-off in xylem transport. Plant Cell Environ 28:800-812

Zimmermann MH (1983) Xylem structure and the ascent of sap. Springer, Berlin

Zwieniecki MA, Holbrook NM (1998) Diurnal variation in xylem hydraulic conductivity in white ash (Fraxinus americana L.), red maple (Acer rubrum L.) and red spruce (Picea rubens Sarg.). Plant Cell Environ 21:1173-1180 